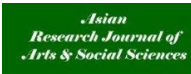

\title{
An Assessment of the Ecotourism Potential of Gashaka Gumti National Park in Nigeria
}

\author{
E. D. Oruonye ${ }^{1^{*}}$, M. Y. Ahmed ${ }^{1}$, Garba A. Hajara ${ }^{1}$ and R. J. Danjuma ${ }^{1}$ \\ ${ }^{1}$ Department of Geography, Taraba State University, Jalingo, P.M.B. 1167, Taraba State, Nigeria.
}

Authors' contributions

This work was done in collaboration among all authors. Author EDO designed the study, performed the statistical analysis, wrote the protocol and first draft of manuscript, did the analysis and report writing. Authors MYA, GAH and RJD contributed in fieldwork observation, measurement, recording and data collection. All authors read and approved the final manuscript.

Article Information

DOI: $10.9734 / A R J A S S / 2017 / 33293$

Editor(s):

(1) Tsung Hung Lee, National Yunlin University of Science \& Technology, University Road, Touliu, Yunlin, Taiwan.

Reviewers:

(1) Tugba Kiper, Namık Kemal University, Turkey.

(2) Kholil, Sahid University, Jakarta, Indonesia. (3) Uzay Karahalil, Karadeniz Technical University, Turkey.

Complete Peer review History: http://www.sciencedomain.org/review-history/19090

Short Research Article

Received $8^{\text {th }}$ April 2017

Accepted $27^{\text {th }}$ April 2017

Published $17^{\text {th }}$ May 2017

\begin{abstract}
National parks have been established in Nigeria to protect, preserve, conserve and manage representative samples of indigenous flora and fauna. This is intended to among other reasons promote ecotourism development in the country. Gashaka Gumti National Park (GGNP) is one of the National parks in Nigeria (the largest in the country) located in the northeast part of the country. This study examined the ecotourism potentials of GGNP. Field observation, interview and questionnaires were used to elicit information from the staff of (GGNP), tourist and enclave communities within the park. Findings from the study show that in past decade (between 2005 2015), the park received 6,713 local and 612 international tourists. $33 \%$ of the international tourists were from Britain. 269 people (35 indigene and 28 non-indigene) were directly employed by GGNP. About $44 \mathrm{~m}(\$ 144,000)$ was generated as revenue in the park within this period. The comparatively low patronage to the park by both local and international tourists is attributable to the remote location and poor accessibility within the park. The study findings revealed that the huge ecotourism potentials of the park are under-utilized at the moment. Some of the challenges include poor funding, lack of adequate publicity, inadequate infrastructure and recreational facility and activities of poachers. The study recommends improvements in road network to and within the Park and stiffer sanctions to curb poaching.
\end{abstract}


Keywords: Gashaka-Gumti; national park; tourism development; wildlife; sanctuary.

\section{INTRODUCTION}

The tourism industry is one of the sectors that Nigerian government is shifting its attention in the face of recent economic challenges facing the country. The rich potentials in Nigeria's game reserves and National parks remained one area that need to be explored. The economic potentials of using the National Parks for ecotourism are enormous and deserve the attention and investment by government. National parks possess ample potentials for recreation and eco-tourism [1,2,3,4,5]. Ngoka [6] observed that National parks, preserving tourism attractions such as wildlife, landscape, scenic sites, waterfalls and geomorphologic features provide the potential for a wide range of tourism activities which include game viewing, mountain climbing, nature appreciation of flora and landscape, warm spring bathing, sport fishing, boating, wilderness experience, birding, nature trail, nature refuge, hiking, excursion, and camping $[7,2,4]$. The ecotourism potentials of parks are the attractions which motivate tourists to embark on tour to such destination $[8,9,10]$.

Gashaka Gumti National Park (GGNP) is one of the National parks in Nigeria (the largest in the country) located at the foot of the Mambilla plateau in northeast part of the country. The Park is a vast land of spectacular wilderness $(6,000$ $\mathrm{km}^{2}$ ) in the southeast corner of Taraba State, adjoining the Mambilla Plateau. Mostly mountainous, from 457 to 2407 meters, it contains Nigeria's highest mountain, Chapal Waddi $(2409 \mathrm{~m})$ [11]. It is the most ecologically diverse conservation area in the country and contains swaths of guinea savannah, gallery forest, moist forest, mountain forest and grassland. It is the most diverse in terms of species in the whole of West Africa, harboring such rare animals like the colobus monkey and warthogs, including buffalo, roam antelope, chimpanzee, hippopotamus, hyena, giant forest hog, lion and leopard. It is home to some highly endangered species of wildlife such as cheetah, red river-hog, mountain reedbuck, sitatunga, African civets, yellow-backed duikers, piping hornbill, green turaco, pangolins etc.

It is an important park that protects the watershed of River Benue in addition to wide range of flora and fauna [12]. The Nigerian Conservation Foundation (NCF), World Wildlife Fund (WWF) and the University College of
London (UCL) have been undertaking research and support project in the park.

Although tourism was an integral part of the objectives that led to the establishment of the national park [13], its tourism capacity and potentials are yet to be fully harnessed [14]. The park has been reported to attract an average of 1000 tourists annually [14]. It has been argued that ecotourism has the potential of promoting sustainable rural development and creating considerable income for adjacent communities $[15,16]$. However, despite its large land area, rich flora and fauna, the park is not among the popularly known park in the country. Thus, not much work has been done to explore the tourist attractions, potentials, capacity utilization, prospect and challenges of the park. This study examines the level of patronage to the park by tourist and capacity utilization of the park.

\subsection{Description of Study Area}

Gashaka - Gumti National Park is situated at the foot of the Mambilla Plateau and covers a land area of about $6,411 \mathrm{~km}^{2}$. It lies between latitude $6^{\circ} 55^{\prime} \mathrm{N}$ and $8^{\circ} 05^{\prime} \mathrm{N}$ and longitude $11^{\circ} 13^{\prime}$ to $12^{\circ} 11 \mathrm{E}$. The park was originally gazetted as Gumti, Gashaka and Serti Game sanctuaries by the defunct Northeast Government in the 1970's. The three game sanctuaries were merged and upgraded to a National park by the Nigeria National Park Decree of $26^{\text {th }}$ August, 1991 which was repealed by Decree 46 of 1999. Gashaka Gumti National Park is a vast land of spectacular wilderness $\left(6,000 \mathrm{~km}^{2}\right)$ in the southeast corner of Taraba State, adjoining the Mambilla Plateau (Figs. 1 and 2). The Park, like any other Park, was established as a protected area for the purpose of nature conservation, recreation, ecotourism, scientific and medical research, and to promote art, craft and other cultural values of the indigenous people of the immediate environment. The Park is an outstanding tourist landmark in Taraba State. Its unique position is underlined by the fact that it is not only the largest of all the eight national parks in the country [17], but it is the most diverse in terms of species in the whole of West Africa, harboring such rare animals like the colobus monkey and warthogs, including buffalo, roam antelope, chimpanzee, hippopotamus, hyena, giant forest hog, lion and leopard. It is home to some highly endangered species of wildlife. Threatened with extinction elsewhere, chimpazees are truly at 
home at Gashaka Gumti park; they are safe, secured, relaxed and confident. Its vast expanse of land contains river valleys and peaks that are suitable to holiday makers. The park is crisscrossed by many rivers (notably rivers Kam, Gashaka, Yim and Gam-Gam) which, among other ecological functions, act as reservoirs of diversity. Visitors to this secluded region will find no roads here, but only a small number of footpaths snaking through the wooded mountains in the direction of Republic of Cameroon. Visitors to the Gashaka-Gumti National Park would be able to take pleasure in the flourishing forests, the extensive sweeping grasslands, the fresh highland plateaus, the rocky mountains, rich wildlife and the captivating ethnic cultures. The climate of the park ranges from tropical to humid at different times of the year.

The ethnic groups in the area are Jibu, Dakka, Ndoro, Tigun, Gbaya, Tiv, Mambilla, Kaka and Fulani in the southern part of the park, while in the northern part or Toungo sector are the Chamba, Kutim Potopore, Fulani, Dakka, Nyamnyam and Kona. The major occupations of the enclave communities are farming, livestock husbandry, vocational jobs, civil service with few hunters and fishermen. They engage in subsistence farming and crops cultivated include maize, groundnut, millet, guinea corn, beans, soya beans, rice, yams, sugar cane, and cassava.

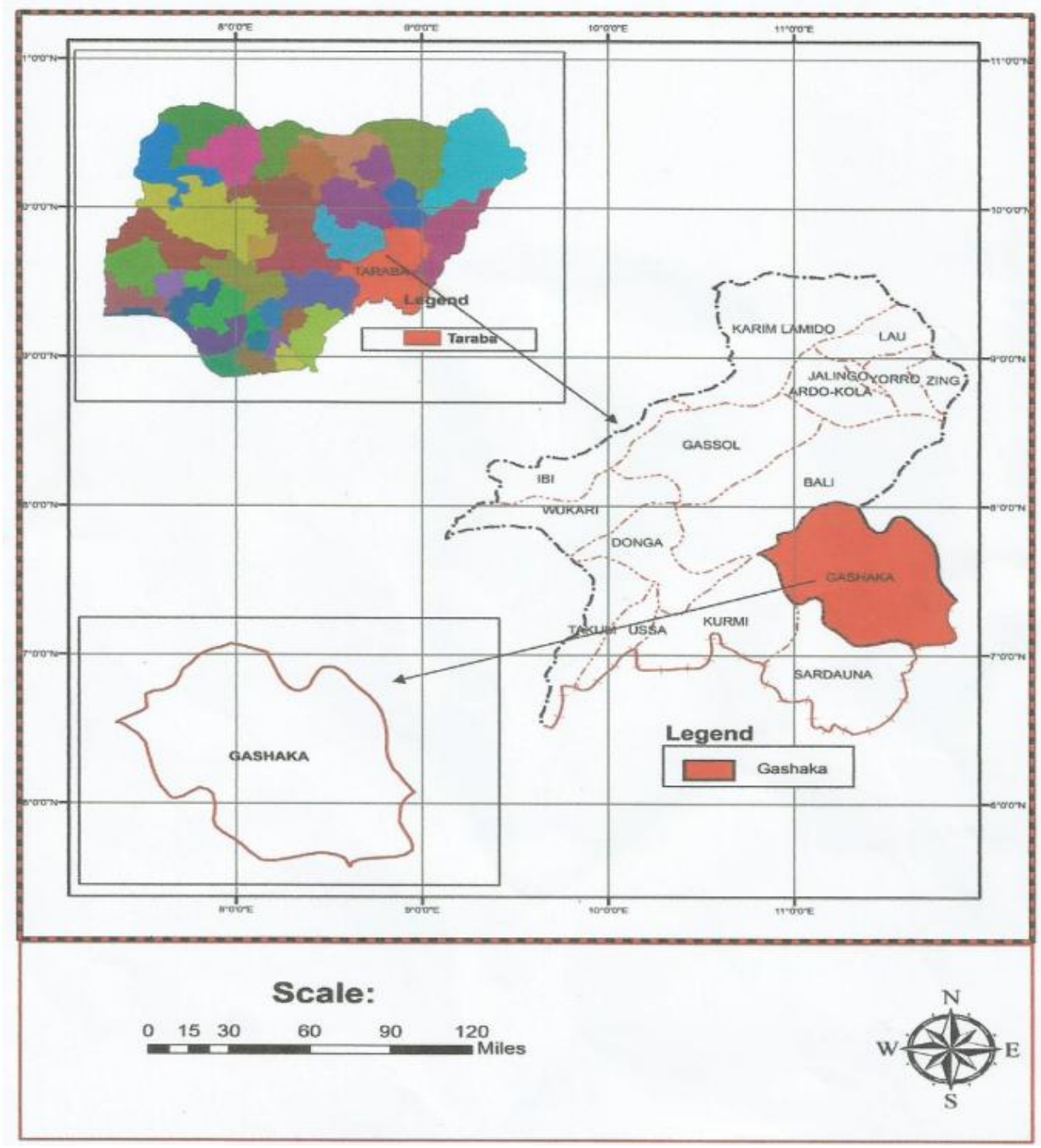

Fig. 1. Location map Gashaka 


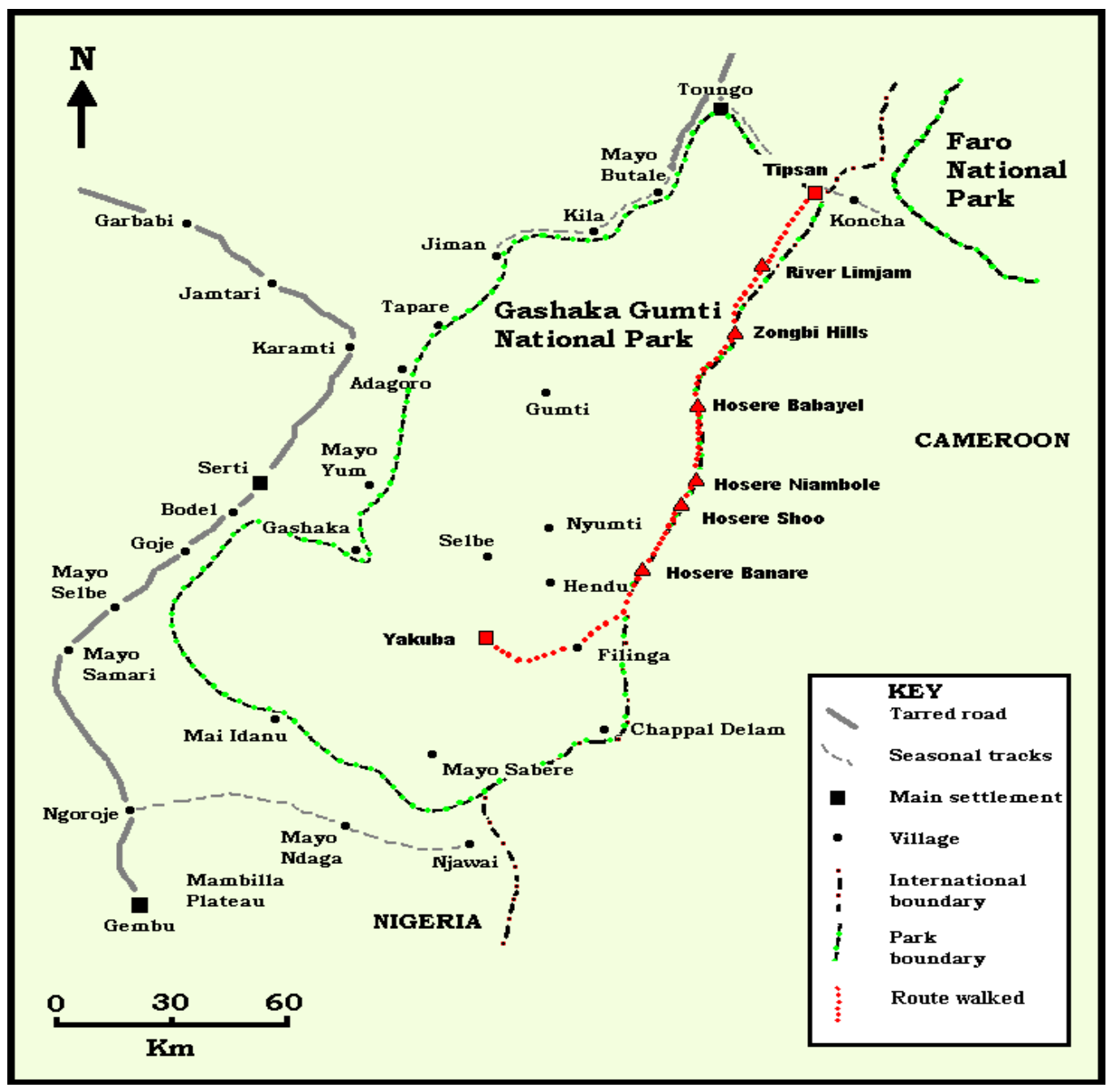

Fig. 2. Map of Gashaka Gumti National Park

The best time to visit the park is during dry season, that is between December to March yearly. This is when the park booms and every condition at its best both in terms of accessibility and the weather. Although one can also visit during the rainy or wet season but extra care would need to be taken, especially because of the weather and the terrain. During the dry season, visitor should expect to battle some cold and so should go with some warm clothing [18]. There are about 25 communities in and around the park; 5 outside, 11 on the periphery and 9 inside, including 6 enclaves [14].

\section{MATERIALS AND METHODS}

The study employed cross sectional survey method in generating information required for the study. Field observation, interview and questionnaires were used to elicit information from the staff of (GGNP), tourist and enclave communities within the park. Questionnaires were administered based on accidental sampling to tourists that were found in the park at the time of visit to elicit information on the tourism attractions visited by respondent and perception about the park. The record of tourism visitation of the park was examined to obtain information on total visitations of the park within study period (TVP). This was used to determine capacity utilization of the park. Hundred questionnaires were randomly issued out to Tourists present in the park at the time of the research, some local community members and staff of GGNP based on availability. However, only 80 questionnaires were successfully retrieved. Descriptive statistics was used to analyze the data collected. 


\section{FINDINGS OF STUDY}

Table 1 shows that total visitation to GGNP for tourism during the period 2005-2015 was 7,325 consisting of 6,713 domestic and 612 international tourists. This shows low patronage or tourist visitation to the park. International tourists visit to the park is an indication of foreign utilization of the ecotourism potentials of the park. Thus, the foreign utilization could also serve as a pointer to the foreign exchange earning potentials of the park and the nation at large from tourism. The study findings also show that most of the international visitors were mainly scholars undertaking research in the park $(33 \%$ from Britain). The decrease in tourist visit to the park after 2012 could be attributable to the general insecurity threat that engulf the north eastern part of the country as a result of insurgent activities (Boko haram). There was also insecurity threat from the conflict between the cattle rearers and crop farmers in the area within this period. The conflicts led to the burning of many settlements in the central part of the state.

\subsection{Revenue Generation by GGNP (2005 - 2015)}

The revenue generated in GGNP for the period 2005 to 2015 is about $\$ 44 m(\$ 144,000)$. The breakdown of the sources of the revenue is presented in Table 2. The Table shows that the highest sources of revenue were generated from accommodation facilities provided to tourists and compensation.

\subsection{Employment Generation of the Park}

One of the major importances of tourism activities is the provision of employment opportunities which could be direct or indirect. Findings from the study show that the management of GGNP has about 269 full time employees and 8 casual staff on its payroll. This consists of 150 indigenes and 119 nonindigenes. The breakdown of this employment status is presented in Table 3 .

Table 1. Tourists visitation to GGNP

\begin{tabular}{llll}
\hline S/No & Year & $\begin{array}{l}\text { No. of domestic } \\
\text { tourists (Local) }\end{array}$ & $\begin{array}{l}\text { No. of } \\
\text { international } \\
\text { tourists (Foreign) }\end{array}$ \\
\hline 1 & 2005 & 166 & 55 \\
2 & 2006 & 80 & 61 \\
3 & 2007 & 282 & 44 \\
4 & 2008 & 90 & 53 \\
5 & 2009 & 276 & 71 \\
6 & 2010 & 1643 & 88 \\
7 & 2011 & 932 & 92 \\
8 & 2012 & 1028 & 50 \\
9 & 2013 & 992 & 61 \\
10 & 2014 & 804 & 12 \\
11 & 2015 & 420 & 25 \\
12 & Total & 6,713 & 612 \\
\hline \multicolumn{4}{c}{ Sources: GGNP, 2016}
\end{tabular}

\subsection{Ecotourism Resources of Gashaka Gumti National Park}

Ngoka [6] observed that the types of attractions existing in a National park affect its rating by tourists, its level of utilization and ultimately its profitability and overall economic performance. This makes it important to consider some of the tourist resources of GGNP. These include;

\subsubsection{The hippo pool}

The "hippo pool" is located $5 \mathrm{~km}$ upstream of River Kam bridge. It provides an ideal opportunity to tourists and researchers to observe the habitats of the hippopotamus at closer range. These hippos are quite accustomed to such visits, remaining calm and undisturbed throughout.

Table 2. Source of revenue generated by GGNP (\$) (2005-2015)

\begin{tabular}{lllllll}
\hline Year & Catering/Bar & Accommodation & Compensation & $\begin{array}{l}\text { Park } \\
\text { entering }\end{array}$ & $\begin{array}{l}\text { Other } \\
\text { source }\end{array}$ & Total (\$) \\
\hline 2005 & 69,800 & 984,050 & 84,100 & 108,500 & $5,200.00$ & $1,251,650$ \\
2006 & 174,340 & $951,675.60$ & 693,850 & $257,576.25$ & $280,251.7$ & $2,357,693.55$ \\
2007 & 9,000 & $242,502.75$ & $323,140.00$ & $173,150.00$ & 302,971 & $1,050,763.75$ \\
2008 & 565,000 & 576,220 & 92000 & 91,500 & 85,940 & $1,410,660$ \\
2009 & 484,720 & $1,115,475.00$ & $1,484,000.00$ & $47,729.75$ & $197,480$. & $3,329,404.75$ \\
2010 & 79,909 & $1,707,800$ & 867,700 & 224,410 & 230,040 & $3,109,859$ \\
2011 & $548,62.2$ & $1,020,174$ & $2,361,360$ & $1,182,260$ & 399,090 & 5,0177462 \\
2012 & $216,75.9$ & $1,679,150$ & $2,416,813.8$ & 423,170 & $3,213,411.4$ & $7,754,221.1$ \\
2013 & 225,955 & $1,475,650$ & $6,453,060$ & 694,800 & 309,060 & $9,158,525$ \\
2014 & 220,065 & 888,500 & $3,984.00$ & $1,113,412$ & $5,955,227$ & $8,181,188$ \\
Total & $1,905,327.1$ & $10,641,197.35$ & $14,776,0238$ & $4,061,508$ & $10,978,670.7$ & $42,781,427.15$ \\
\hline \multicolumn{7}{c}{ Source: Annual report (GGNP) }
\end{tabular}


Table 3. Employment status of GGNP by department

\begin{tabular}{lll}
\hline S/No & Employment cadre & Total no. \\
\hline 1 & Ecology & 179 \\
2 & Administration & 20 \\
3 & Accounts and audit & 16 \\
4 & Works and maintenance & 25 \\
5 & Eco-Tourism & 18 \\
6 & RP/ICT & 11 \\
7 & Total & 269 \\
\hline \multicolumn{2}{c}{ Sources: GGNP, 2016 }
\end{tabular}

\subsubsection{The German forte}

This is the ruins of pre-colonial 1918 German forte situated on the small hill overlooking Gashaka village. It is of historical importance, with lots of archaeological materials and the ruins of German administrators' near Garbabi village on the road to Bali.

\subsubsection{GGNP museum}

The Park has museums of Natural History at the Head Office at Serti and Toungo Range office (Plate 1).
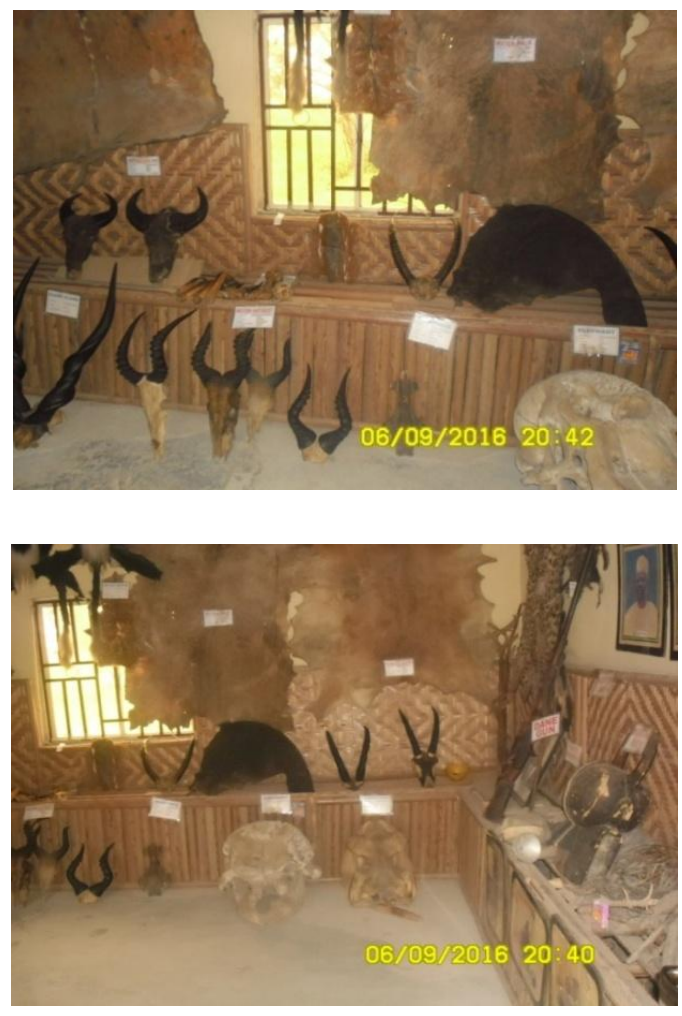

Plate 1. GGNP Museums and historical artefacts
Skins of different wildlife specimens, fishing gears, old hunting equipment, carved footprints of some animal species etc are displayed in the museum. These specimens are sampled representative of the abundant fauna and flora resources of the Park.

\subsubsection{Game trail}

At game watch, which is usually enjoyable at the early hours of the day and late afternoons, some of the fauna to catch up with on the trail include chimpanzee, leopard, water buck, warthog, bush buck, hartebeest, giant eland, hunting dog, red river hog and kob. Others are antelope, lion, mona monkey, black and white colobus, buffalo, hippopotamus and red flanked duiker.

\subsubsection{Primate watching}

GGNP is a very important stronghold of primates, particularly, the forests in Chappal Waddi, Chappal Hendu, Chappal Yumti, Chappal Sirgu and Kwano forest. One is certainly sure to sight chimpanzees, baboons and different types of monkeys here or at least hear their calls or see their nests.

\subsubsection{Bird watch}

Bird watch is also an important leisure activity of tourists to the park (Plate 5). The park is a birdwatcher's paradise with a wide variety of species. Birdwatchers would be glad to know that there are a wide variety of bird species here. The Park is one of the most important bird areas in Africa. The park has been classified as Important Bird Areas (IBAs) of International importance for bird conservation. Birdwatchers are able to find more than 500 species [19]. The birds range from indigenous to migratory birds, so ornithologists would find the park a place of succour to explore, as there is a lot to feast on. Visiting bird watchers will discover that new species are constantly added to their list.

\subsubsection{The Mayo Kam river}

The river Kam is the parks' largest river. In dry season, the crystalline clear water is full of fish in addition to small group of hippos and crocodiles (Plate 3). During this time, it is possible to follow the river upstream, southward to the park boundary, returning to Gashaka via Mai Idanu and Mayo Kpea passing through woodland and forest. 

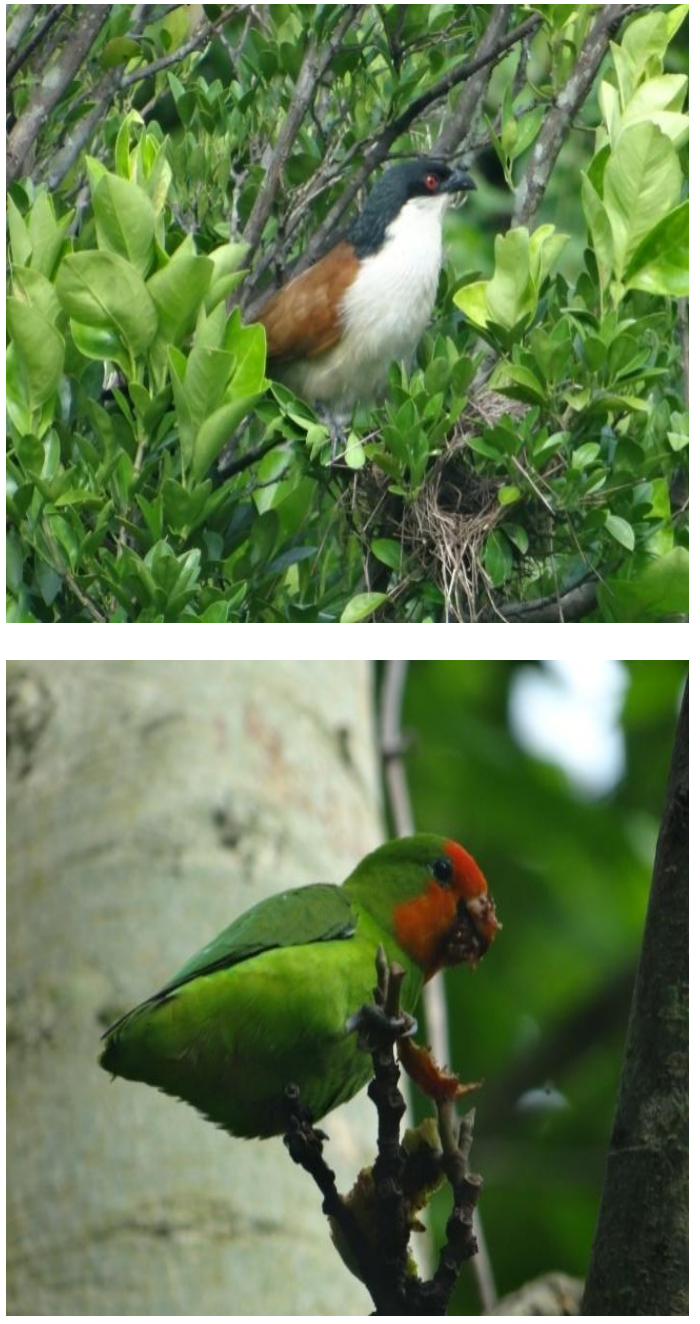

Plate 2. Beautiful birds at the GGNP Park

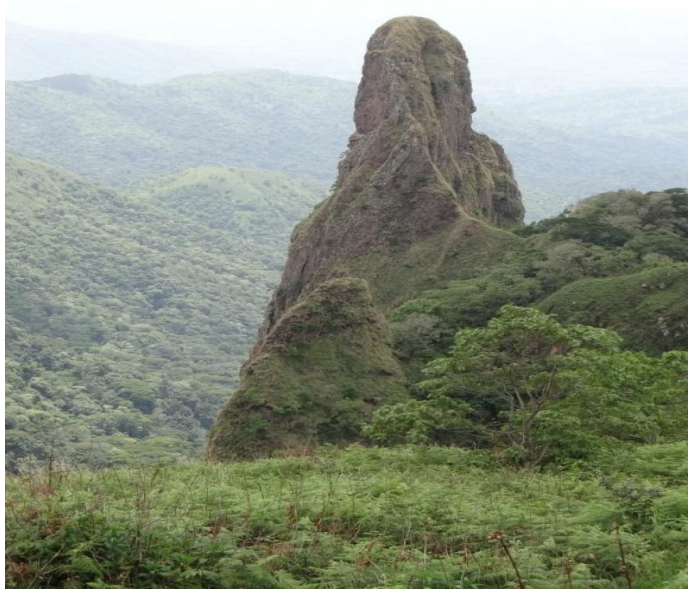

Plate 3. Chappal Waddi

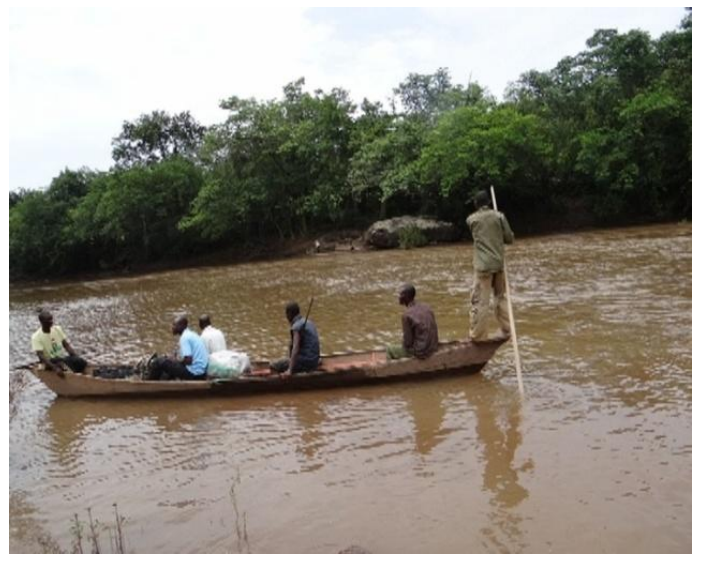

Plate 4. Boating activities at Mayo Kam River

\subsubsection{The forest of Kwano}

The old abandoned village site of Kwano is an excellent location from which to explore rain forest on the lower slopes of Chappal waddi mountain. These forests represent some of the best site for primate watching in the park. Kwano is accessible through footpath from Gashaka village (3 hours walk). Chimpanzees are abundant here, in addition to baboons, putty nosed monkeys, Mona monkeys and black and white Columbus monkeys. Other animals include yellow - black duikers, red river hog, giant forest hog, buffalos, bush back and leopards.

\subsubsection{The Dumti Lake around Mayo Bakari}

Each dry season large concentration of animals and birds congregate around several small lakes located in the vicinity of Mayo Bakari. Some of these animals include Cob, Heart beast, Warthogs, Baboons, Patas monkeys and Lion while the birds' ranges from Hammer Cock, White Crown Plover, Giant King Fisher, Red throated bee-eater etc. Mayo Bakari is easily accessible from Toungo.

\subsubsection{Kiri water fall (Toungo)}

There are many waterfalls in the park, but the Kiri waterfall in Toungo end of the park is the most attractive site to visit to see and savour the ambience of nature. It is a sight to behold as one watches the water gushing out in torrential force and cascading downward from its lofty height to form a large and natural swimming pool at the base [18]. The park organized package tours to Kiri water fall in Toungo (northern sector) using experience park rangers. 


\subsubsection{The bat forest}

The bat forest or Kurmin Jamage, so called because of large number of fruit bat that roots in this area. The area can be visited from Gashaka village (a day trip). Variety of other animals can also be seen here.

\subsubsection{Mountaineering}

GGNP has vast highlands and hilly ranges which are very suitable for mountaineering and cave exploration. The park contains the highest mountain peak in Nigeria, the "Chappal Waddi", literally translated as "the mountain of death" with an altitude of 2,400ma.s.l. The mountain is located in the Gotel mountain range. It is characterized by steep, forested slopes, deep plunging valleys, precipitous escarpments and swift flowing rivers, streams, hot spring and waterfalls.

\subsubsection{Safari and nature walk}

The Safari and nature walk is one of the important leisure activities that prospective visitors to the park would look forward to. The massive size of the park assures visitors to the park of exciting moment and thrills, especially if one can keep up with the trail, which usually takes some hours or even days to cover. No matter the hours or days one spends in covering the vast park while on safari, the experience is something that is sure to create lasting memory.

\subsubsection{Well-paved trail tracks}

There are well-paved trail tracks in the park, which sometimes are rugged and steeples. The park has well trained guides (Plate 7) that accompany tourist to their areas of interest within the park. As one makes it through the twist and turns of the park, one is regaled with fascinating tales by the guides.

\subsubsection{Sport fishing}

GGNP has an ideal spots for sport-fishing activities such the Mayo Kam River, near the Hippo-pool. In the dry season the water is very clear, making it easy for one to see the different types of fish in the area ranging from Tiger, Cat fish, Nile perch, Tilapia fish among others. The rivers of GGNP provide important feeding, spawning and nursery areas for migratory fish stocks of the River Benue.

\subsubsection{Outdoor camping}

The park management has designated some sections within the park for camping and picnic with camping facilities such as tents provided for people who want to explore life in its rustic and wild elements [18].

\subsubsection{Hot spring}

Hot springs is found near Gashaka village, close to Mayo Jiagumand on the southern park boundary and at Matashirip.

\subsubsection{Tourist facilities in GGNP}

The Park has a rest house which provides selfcatering accommodation at small fee. Lodging facilities exist for visitors wishing to stay overnight at the park. The total installed accommodation capacity in the sectors are 41 rooms ranging from suite (2), luxury (7), single rooms (19), VIP (11) and studio (2). The rooms are (Plate 5) furnished and equipped with facilities and different hospitality gadgets for the use and comfort of the visitors. The park management has provision of viewing vehicles to make it easier for visitors to have frolicking moment at the park. The park is best explored on foot and it is possible to hire game guards; guides and porters at Serti or in Gashaka village. The Park has a conference centre, hall and open space for outdoor activities. However, there are no well developed sporting facilities such as lawn tennis, badminton, squash, table tennis, golf, dart and card games.

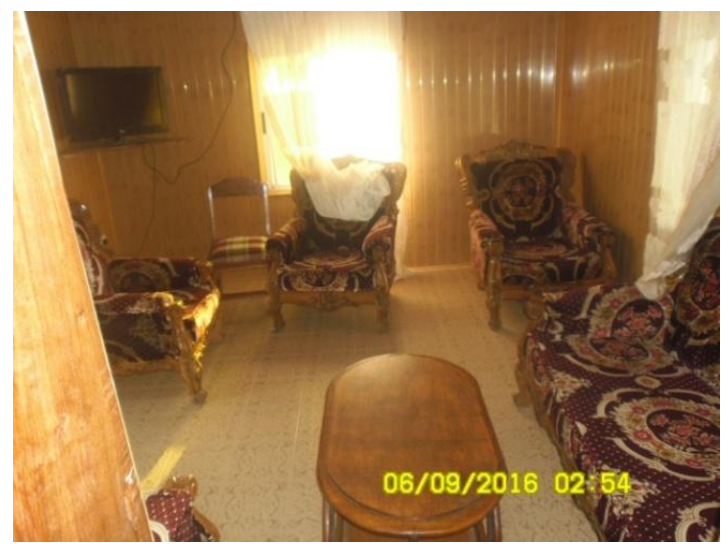

Plate 5. Accommodation category (suite)

\subsubsection{Challenges of ecotourism at GGNP}

The findings of the study show that there is low patronage to GGNP which suggest 
underutilization of the park's potentials. This translate to low revenue generation of GGNP and subsequently low economic performance. This result corroborated the findings of [1] which reported underutilization of existing potentials of African Parks as a reason for their low economic performance. This made the parks unable to contribute meaningfully to the economies of their host communities or countries.

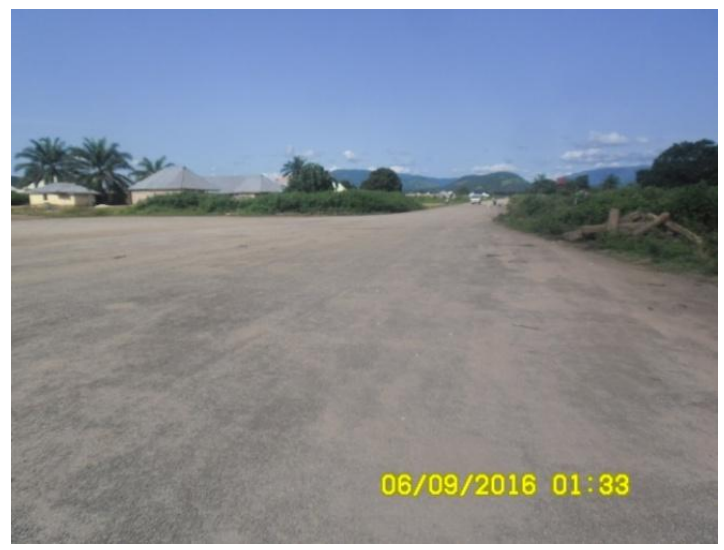

Plate 6. Proposed Airstrip at Serti, Baruwa town

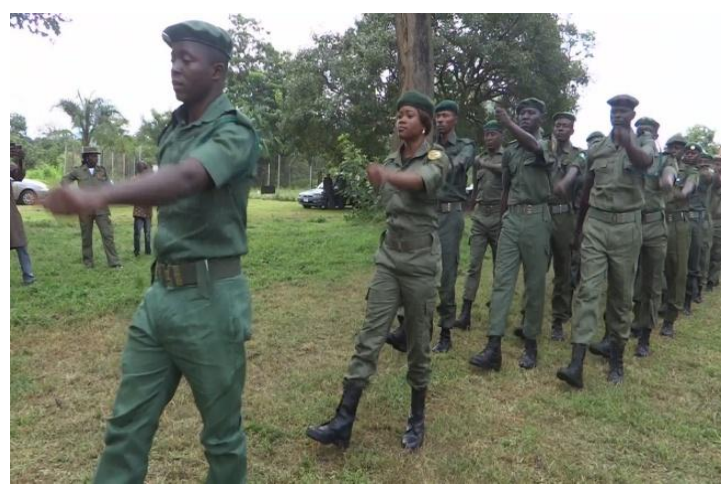

Plate 7. GGNP park rangers

Eltringham [1] observed that wildlife is the major tourist attraction to national parks in SubSaharan Africa. Honey [20] noted that lions and elephants attract more tourists than other species in Africa parks. Although GGNP contains reasonable number of wildlife populations, they might not be the type that many tourists were eager to see. The hilly nature of the terrain and dense vegetation may constitute obstacle to game viewing in the park. Although, Lions and elephants were said to exist in GGNP, they may often not be readily sited in the park. Chimpanzees and Baboons are more in population density and have greater ease of sighting in the park.

Many scholars believed that Nigerian national parks are under utilised for ecotourism development in spite of their abundant pristine attractions [9,5,21,3]. Ngoka [6] observed that factors such as inadequate policy framework, lack of adequate statistical data on the tourism potentials within the parks, poor tourism infrastructure, facilities, poor management and services and insecurity have been blamed for the low utilization of existing capacities $[8,5]$. The park is not yet fully developed since the roads leading to it as well as the viewing tracks are not well developed. This poor accessibility within the park which makes game viewing often restricted to trekking on foot is a major limiting factor to maximum utilization of the park tourism resources. Also there is a proposed airstrip in the area that has been abandoned (Plate 6). The completion of the airstrip will greatly boost tourism activities in the park.

Ngoka [10] reported that awareness of a park's tourism potentials is a significant determinant of utilization. GGNP seems to be a least popularly known Park as a tourism destination in the country. The Yankari National Park located in Bauchi State, Nigeria, is perhaps the most popular eco-destination in West Africa sub-region [22]. This agrees with earlier speculations by Oriero $[9,5,21,3]$ of low awareness of conservation areas as tourism destinations in Nigeria and, specifically low utilization of national parks for tourism despite the abundance of tourism potentials within them. GGNP is located in the north earstern part of Nigeria which has suffered greatly from the activities of insurgent groups (Boko haram). There has been fear of the park serving as hideout to fleeing members of this insurgent group. This singular security threat is enough to affect international visit to the park within the study period.

This study finding agrees with earlier study carried out by Obioma [23] that it is unfortunate that tourism development in Nigeria has been threatened by such factors like financial problems, infrastructural constraints like poor road network, electricity, drinkable water, health facilities and lack of awareness among Nigerians on the benefits of tourism to the expected tourists and other Nigerians.

According to Global Environmental Fund GEF [24] document, with few tourists visiting Nigeria, 
the economic potential of ecotourism at GGNP is fairly low, and offers little opportunity for significant revenue generation. However, its diversity of habitats, rich biodiversity and dramatic landscapes offer great opportunity for ecotourism should this situation change.

\section{CONCLUSION}

This study has examined the ecotourism potentials of GGNP. Findings from the study have shown low patronage to the Park in the past decade. The comparatively low patronage to the park by both local and international tourists is attributable to the remote location and poor accessibility within the park. The study findings revealed that the huge ecotourism potentials of the park are under-utilized at the moment. The park has enormous potentials that have not been fully harnessed. There are about 269 people (35 indigene and 28 non-indigene) that were directly employed by GGNP which is low. Also the amount ( $\$ 44 \mathrm{~m}$ or $\$ 144,000$ ) generated as revenue in the park in the last decade is very low. Scholars have opined that gaining insight into the utilization levels of specific parks can provide opportunity to better appreciate the challenges of ecotourism and how best to solve them. Some of the challenges include poor funding, lack of adequate publicity, inadequate infrastructure and recreational facility and activities of poachers. The study recommends improvements in road network to and within the Park, funding and stiffer sanctions to curb poaching.

\section{RECOMMENDATIONS}

Based on the findings of this, it is recommended that Government should invest more money to the development of tourism in the area as tourism development requires heavy initial investment. There is need also to improve the road network to and within the Park and other infrastructural facilities. The recreational facilities and hotel accommodation in the Park will require upgrading to attract international visitors and very important personality. Of particular importance is the completion of the old and abandoned airstrip in the area. Government should also implement stiffer sanctions to curb poaching in the park.

\section{COMPETING INTERESTS}

Authors have declared that no competing interests exist.

\section{REFERENCES}

1. Eltringham BK. Wildlife resources and economic development. New York, John Wiley and Sons Ltd.; 1984.

2. Ayodele IA, Falade GO. Some aspects of the tourism potentials of Nigerian National Parks. In A. C. Boyown (Ed.), Environment and tourism in Nigeria. Lagos, Environment and Behaviour Association of Nigeria. 1993;211-218.

3. National Park Service. Saving Nigerian's vanishing wildlife for eco-tourism. In A. A, Oshintoki Nigeria National Parks. Abuja: National Park Service. 2004;5-12.

4. Obua J. The potential, development and ecological impact of eco-tourism in Kibale National Park, Uganda. Journal of Environmental Management. 1997;50(1): 27-38.

5. Lameed GA. Ecological considerations for the management of endangered primate species of Cross River National Park: Implications for eco-tourism development (Doctoral thesis). Submitted to the Department of Wildlife and Fisheries Management, University of Ibadan; 1999.

6. Ngoka PC. Capacity and levels of utilization of tourism potentials of Yankari and Cross River National Parks implications for optimistic ecotourism development in Nigeria. African Journal of Hospitality, Tourism and Leisure. 2013; 2:4.

7. Ozo AO. Urban landscapes in tourism development in Nigeria. In A. C. Boyown (Ed.), Environment and tourism in Nigeria. Lagos, Environment and Behaviour Association of Nigeria. 1993;63-76.

8. Tumber UK. The tourism industry in Nigeria. In A. C. Boyown (Ed.), Environment and tourism in Nigeria. Lagos, Environment and Behaviour Association of Nigeria. 1993;295-306.

9. Oriero SB. Wildlife and tourism in Nigeria. In A. C. Boyown (Ed.), Environment and tourism in Nigeria. Lagos, Environment and Behaviour Association of Nigeria. 1993;219-232.

10. Ngoka PC. Recreational potentials and levels of utilization of Yankari and Cross River National Parks. (Doctoral thesis). Submitted to the Department of Health and Physical Education, University of Nigeria, Nsukka; 2007.

11. Oruonye ED, Ahmed YM, Ejati TH. Prospect of tourism development on the 
Mambilla Plateau: Lessons from Obudu mountain resort, Nigeria. IRA-International Journal of Management \& Social Sciences. 2016;5(1):87-97.

12. Obot E. Linking tourism profitability to environmental responsibility: The Okwangwo experience and the GashakaGumti Potential. In Aremu D.A. (Ed.) Preservation of Land, Culture and Wildlife for the Development of Ecotourism in Africa. Spectrum Books Limited, Ibadan Nigeria. 2008;56-60.

13. Sommer V, Ross C. Exploring and protecting West Africa's primates: The Gashaka Primate Project in context. In: V. Sommer and C. Ross (eds.), Primates of Gashaka: Socio- ecology and Conservation in Nigeria's Biodiversity Hotspot. Springer Science+ Business Media: New York. 2011;1-37.

14. Dishan EE, Agishi R, Akosim C. Women's involvement in non-timber forest products utilization in support zones of Gashaka Gumti national park. Journal of Research in Forestry, Wildlife and Environment. 2010;2(1):73-84.

15. Jarvis TD. The responsibility of National Parks in Rural Development. In: Machlis, G.E., Field, D.R. (Eds.), National parks and rural development: practice and policy in the United States. Island Press, Washington, DC. 2000;219-230.

16. Mayer $M$, Mullerb $M$, Wolteringa $M$, Arneggera J, Joba $H$. The economic impact of tourism in six German National
Parks. Landscape and Urban Planning. 2010;97(2):73-82.

17. Ayodele Al. Management of tourism potentials in Nigerian national parks. In Aremu, D.A. (Ed.) Cultural and Ecotourism Development in Nigeria: The role of the three tiers of Government and the Private Sector. Hope Publication, Ibadan, Oyo State pNigeria. 2001;136-143.

18. Okungbowa Andrew Iro. The delight of Gashaka Gumpti. The Guardian Newspaper, Saturday. May 16; 2009.

19. Oruonye ED, Abbas B. The geography of Taraba State, Nigeria. LAP Publishing Company, Germany; 2011.

20. Honey MS. Tourism: A force for good. Awake. 2005;86(16):1-9.

21. Nigeria Tourism Development Corporation (NTDC). Nigerian Tourism. 2001;1:2.

22. Olokesusi F. Assessment of the Yankari game reserve, Nigeria: Problems and Prospects. Butterworth Heineman Ltd. 1990;153-155.

23. Obioma BK. Tourism potentials and socioeconomic development of Nigeria: Challenges and prospects. RIJSER Special Edition. 2013;7:2.

24. Global Ecological Fund (GEF) Project Document. Transboundary Collaboration for Ecosystem Conservation: The Mountain Forests of Gashaka- Gumti National Park, Nigeria and Tchabal Mbabo, Cameroon. United Nations Development Programme; 2001.

(C) 2017 Oruonye et al.; This is an Open Access article distributed under the terms of the Creative Commons Attribution License (http://creativecommons.org/licenses/by/4.0), which permits unrestricted use, distribution, and reproduction in any medium, provided the original work is properly cited. http://sciencedomain.org/review-history/19090 